\title{
Body Weight and the Quality of Interpersonal Relationships*
}

DEBORAH CARR

\author{
MICHAEL A. FRIEDMAN
}

Rutgers University

\begin{abstract}
We investigate whether underweight, normal-weight, overweight, and obese Americans differ in their evaluations of positive and negative aspects of their interpersonal relationships. Analyses are based on data from the Midlife Development in the United States (MIDUS) study, a survey of more than 3,000 adults ages 25 to 74 in 1995. We find no significant differences across the body mass index (BMI) categories in the quality of relationships with friends, coworkers, and spouses. Severely obese persons report significantly higher levels of strain and lower levels of support in their family relationships. This pattern, however, is contingent upon one's adolescent body weight. Among persons who were of "normal" weight at age 21, current BMI is not associated with relationship quality. For persons who were overweight at age 21, the level of social support received from family during adulthood declines as adult BMI increases. Implications for stigma theory are discussed.
\end{abstract}

The prevalence of obesity has increased rapidly in the developed world over the past 20 years. The World Health Organization (1998) describes this pattern as a "global epidemic." In the United States, one-quarter of adults are obese, with a body massitindex (BMI) of 30 or higher; 50 to 60 percent are classified as overweight or obese with a BMI of 25 or higher (Flegal et al. 2002). Although obesity is increasingly common in the United States and elsewhere, obese individuals still are regarded as one of the last acceptable targets of stigmatization (Allon 1981; Carr and Friedman 2005; Puhl and Brownell 2001, 2003). Unflattering portrayals of obese persons pervade popular culture, while multiple studies document that children, adults, and even health care professionals who work with obese patients hold negative attitudes

* An earlier version of this paper was presented at the 2005 annual meetings of the American Sociological Association. Helpful suggestions were offered by Karen Jaffe, the anonymous reviewers, and the journal editor. A public use version of the Midlife Development in the United States (MIDUS) survey is available from the Inter-University Consortium for Political and Social Research (ICPSR) at the University of Michigan (www.icpsr.umich.edu). Address all correspondence to Deborah Carr, Institute for Health, Health Care Policy and Aging Research, Rutgers University, 30 College Ave., New Brunswick, NJ 08901; carrds@sociology.rutgers.edu. towards them (Crandall and Schiffhauer 1998; Greenberg et al. 2003).

Although multiple studies document the pervasiveness of prejudicial attitudes toward obese persons, few researchers have explored whether overweight and obese adults themselves experience poorer relationships with significant others, including spouse, family, friends, and coworkers. This line of inquiry is important, given the well-documented links between social relationships and emotional and physical health (Cohen and Syme 1985). Supportive relationships may help individuals to manage their weight and may help to buffer against the distress associated with weight-based discrimination and health problems (House, Landis, and Umberson 1988). Strained relationships, in contrast, may contribute to the onset and persistence of obesity, and may exacerbate weight-related health concerns (Okun and Keith 1998).

The purpose of our study is to explore the relation between body weight and the perceived quality of interpersonal relationships in the United States. We use data from the Midlife Development in the United States (MIDUS) survey, a random sample of more than 3,000 men and women ages 25 to 74 in 1995, in order to examine whether positive and negative interactions with family members, friends, spouse, and coworkers differ among underweight, normal-weight, over- 
weight, and obese Americans; to evaluate whether the observed association between body weight and relationship quality is moderated by demographic characteristics and by one's weight in young adulthood (age 21); and to investigate whether the association between body weight and relationship quality can be explained by one's childhood family relations, and by the intrusiveness of obesity on everyday behaviors and practices.

\section{BACKGROUND}

\section{The Stigma of Obesity}

Obesity is considered one of the most enduring social stigmas (Cahnman 1968). Goffman (1963:3) defined stigma as any personal attribute that is "deeply discrediting" to its possessors: these attributes include "tribal stigmata," "abominations of the body," and "blemishes of individual character." Obese Americans are stigmatized along the latter two dimensions (DeJong 1980). Research conducted over the past 40 years shows that obese persons are described as physically unattractive and undesirable (Harris, Harris, and Bochner 1982; Puhl and Brownell 2001d Obese individuals also are viewed as responsible for their weight because of some character flaw or "blemish" such as laziness, gluttony, or lack of self-discipline and selfcontrol (e.g., Allon 1981; Crandall and Schiffhauer 1998; DeJong 1980; Harris et al. 1982).

Given the vast amount of evidence documenting prejudicial attitudes towards obese and overweight persons, one might conclude that they also experience less supportive and more critical relationships with significant others, including family members, friends, spouses, and coworkers. Stigmatized persons who are accustomed to criticism and discrimination may anticipate and then reciprocate this negative treatment, which in turn may impede the formation of new relationships (Link et al. 1989) or strain their current relationships (Snyder, Tanke, and Berscheid 1977). Negative treatment also may damage stigmatized persons' self-esteem and mood; low self-esteem and depressed affect, in turn, are associated with poorer interpersonal relationships (e.g., Crocker and Major 1989; Giesler, Josephs, and Swann 1996). Inter- personal rejection, whether actual or perceived, also may reduce obese persons' opportunities to develop strong social skills (e.g., Goldman and Lewis 1977).

Classic writings on stigma suggest, conversely, that some "discredited" individuals, including overweight and obese persons, may experience close personal relationships that are as good as those of their slimmer peers, if not better. Goffman (1963:19-20) observed that stigmatized individuals may choose purposely to interact with "sympathetic others" who will "share with [them] the feeling that [they are] human and...normal in spite of appearances and in spite of [their] own selfdoubts." These "sympathetic others" fall into two categories. The first category includes those who also carry the stigma: persons who share a discredited attribute, such as obesity, may offer one another acceptance, emotional and moral support, and empathy. The second group comprises "wise persons" who are "privy to the secret life of the stigmatized individual and sympathetic with it" (Goffman 1963:28). In most cases, "wise persons" develop empathy and an understanding of the stigmatized person's plight because they are related to him or her, whether through blood, marriage, or another social structural tie. Consequently they may share some of the discredit of the stigmatized person; yet they also may embrace, accept, and defend the stigmatized individual (Goffman 1963:30-31).

Family members, spouses, and (to a lesser degree) friends may fall into one of Goffman's two "sympathetic" categories, and thus may treat obese persons as well as they treat non-obese persons. First, the significant others of obese persons may themselves be obese. A large literature documents that individuals tend to choose friends and spouses who are equal to themselves in physical attractiveness, and who also are similar in ethnicity, social class, and age (McPherson, Smith-Lovin, and Cook 2001); the latter three characteristics are widely documented risk factors for obesity (Flegal et al. 2002). Biological family members also are likely to share a genetic predisposition for their body weight, although more severe obesity tends to be more heritable than lesser variations in body weight (Snyder et al. 2004). In addition, 
family members, spouses, coworkers, and friends may share a social environment or lifestyle that increases (or protects against) the risk of obesity (e.g., Craig and Truswell 1990; Cutting et al. 1999).

We propose that the association between one's body weight and the quality of interpersonal relationships is more nuanced than suggested above. Specifically, we argue that this association is contingent upon structural aspects of such relationships, including voluntariness and permanence. Voluntariness refers to whether one chooses to enter a relationship; permanence refers to whether one is able to terminate a relationship. Family ties, particularly relationships with blood relatives such as parents, siblings, and children, are involuntary and are based on a powerful sense of obligation (Litwak 1981). Friendships, marriages, and (to a lesser degree) coworker relationships are entered voluntarily; most individuals choose to befriend, marry, or work with persons who are quite similar to themselves (McPherson et al. 2001).

Friendships are considered the least permanent of the four types of relationships. Friendships exist solely for companionship; these ties can be severed, with minimal costs, when the relationship ceases to be emotionally rewarding (Wellman et al. 1996). Family ties, in contrast, cannot be terminated easily: family members have obligatory social roles that they cannot readily abandon (Fischer 1982). Individuals may dissolve their ties with spouses or coworkers without violating important social norms regarding obligation and commitment, although they may incur some short-term emotional or financial costs from ending these relationships (for a review, see McLaughlin, Horwitz, and White 2002). ${ }^{1}$ We expect to find that body weight is associated with relationship quality for only those relationships which are entered and maintained involuntarily. Obese individuals who suffer poor treatment or lack of support in

1 Although normative pressures prevented American married couples from divorcing during most of the twentieth century, two-thirds of Americans now believe that divorce is acceptable if the spouses are unhappy in their marriage (Taylor 1998). their marriages, careers, or friendships may sever their ties and form new, more rewarding relationships. In contrast, most persons with strained or unsupportive parental, sibling, or filial relationships typically maintain these relationships over the long term regardless of the personal costs (Levitt, Silver, and Franco 1996).

We know of no large-scale, nationally representative studies that have investigated systematically the links between body weight and perceptions of one's interpersonal relationships. Although a handful of studies have examined whether obese persons have poorer social relationships than their non-obese peers (e.g., Sobal, Rauschenbach, and Frongillo 2003), these studies typically use small, nonrepresentative samples of women only, or quasi-experimental designs that evaluate weight-based differences in the quality of fleeting social interactions with strangers (e.g., Buhrmester et al. 1988; Miller et al. 1990, 1995). The large MIDUS sample allows us to address five important issues that have been neglected in past studies.

First we examine the association between body weight and both positive and negative aspects of interpersonal relationships with four different categories of significant others: family members, spouses, friends, and coworkers. Positive interactions refer to encounters marked by warmth, acceptance, and emotional support; negative interactions refer to unpleasant social encounters characterized by criticism and rejection (Rook 1984). Both perceived negative and perceived positive interactions may occur within a single relationship (Rook 1998). These two attributes are independent constructs, not simply opposite poles of a single factor (Vinokur and van Ryn 1993). As such, each dimension has distinctive consequences for well-being: relationships distinguished by criticism, conflict, and excessive demands may affect health and well-being more strongly than do beneficial social interactions (Finch et al. 1999; Okun and Keith 1998).

Second, we move beyond the oversimplified dichotomy of "obese" versus "nonobese," and consider the distinctive consequences of being underweight, normal weight, overweight, and two categories of obese: persons with a BMI between 30 and 35 
(obese I) and those with a BMI of 35 or higher (obese II/III). Obese individuals are a heterogeneous population; yet few studies examine whether interpersonal interactions vary at different points on the BMI continuum (Puhl and Brownell 2003). This limitation may reflect the fact that once human differences are identified and labeled, such as "obese" versus "normal," they are taken for granted as meaningful demarcations despite enormous variability within the categories (Link and Phelan 2001).

Third, we examine whether the association between body weight and interpersonal relationships persists when important demographic, socioeconomic, and health characteristics are controlled. These characteristics may confound the observed relationship between body weight and the quality of one's interpersonal relationships. Although past studies have explored whether obese and non-obese persons differ in regard to perceived family strain, most such studies are based on very small samples and do not control for possible confounding factors (e.g., Friedman et al. 1997). Demographic characteristics, including being female, black middle-aged, and less highly educated, increase one's risk of being overweight (Flegal et al. 2002). Each of these demographic characteristics also is associated with the nature and quality of one's interpersonal relationships (Antonucci 2001). In addition, we adjust for physical and psychological well-being in our analyses. Depressed individuals appraise social interactions more negatively than nondepressed persons (Gotlib and Meltzer 1987). Both emotional and physical problems that trigger negative mood also may provoke negative responses from significant others (Coyne 1976; Coyne et al. 1987).

Fourth, we assess whether the association between body weight and the quality of one's interpersonal relationships varies on the basis of one's other demographic and socioeconomic characteristics. The extent to which a personal attribute such as obesity is devalued, and whether that attribute elicits criticism from others, is contingent upon social context (Crocker, Major, and Steele 1998; Link et al. 1989). Obese persons belonging to social strata and subcultures where obesity is less acceptable may be par- ticularly likely to receive criticism and insufficient emotional support from significant others. Whites, highly educated persons, younger persons, and those with richer economic resources are more likely to place great value on slimness and to internalize negative attitudes toward obese persons (Averett and Korenman 1999; Crandall and Martinez 1996). Definitions of physical attractiveness also are tied more closely to slenderness for women than for men (Friedman et al. 2002). Thus it is possible that the interpersonal consequences of obesity are most acute for those who are white, female, young, and of high socioeconomic status. Here we examine whether the association between body weight and quality of interpersonal relationships is conditional upon one's race, gender, age, and occupational status.

Finally, we evaluate whether the association between adult BMI and relationship quality is contingent upon one's early (age 21) body weight. The interpersonal consequences of belonging to a stigmatized group may vary on the basis of whether one has possessed his or her stigmatizing attribute throughout life ("inborn stigma") or whether one acquires the attribute later in life (Goffman 1963:34). Modified labeling theory (MLT) suggests that persons who possess or acquire a stigmatized identity early in the life course may be particularly susceptible to the harmful interpersonal and social consequences of that identity (Link et al. 1989). In brief, MLT proposes that people are socialized to develop and internalize a set of beliefs about members of some stigmatized group. The more strongly individuals believe that they will be devalued or will suffer discrimination because of their stigmatized identity, the more threatened they feel in interactions with others.

Stigmatized persons who believe that they will be devalued typically adopt one of three adaptive strategies: they may keep their identity a secret, they may try to educate others about their situation, or they may withdraw socially. Obese persons, however, simply cannot conceal their physical size. Moreover, given pervasive negative attitudes towards obese persons (e.g., Allon 1981; Crandall and Schiffhauer 1998; DeJong 1980; 
Harris et al. 1982; Puhl and Brownell 2001, 2003), it is unlikely that overweight persons, particularly young people, can enlighten others and thus ward off negative attitudes (e.g., Schneider and Conrad 1980). Rather, the most likely outcome for obese young adults is the expectation of rejection, and, consequently, social withdrawal. (An additional strategy is carefully limiting social interaction to "wise" persons [Goffman 1963], or to those who know about and accept the stigmatized condition.)

In keeping with the core ideas of MLT, an emerging body of research suggests that persons who were overweight early in life but who lose weight later do not ultimately enjoy the same body image, self-confidence, or social ease as persons who were never overweight. The "phantom fat" of formerly overweight persons continues to affect their self-image; this outcome, in turn, may affect their interactions with significant others (Cash, Counts, and Huffine 1990). Moreover, overweight and obese adolescents are more socially isolated and have fewer friends than their more slender peers (Strauss and pollack 2003). Their early experiences of social isolation and rejection may impede the development of social relations in the longer term, even among those who eventually lose weight. Conversely, a person who enjoyed "normal" weight early in life but who later becomes obese may not readily "reidentify" himself or herself (or relate to others) as a member of a stigmatized group (Goffman 1963:34). Thus we propose that relationships with significant others may be affected by one's weight trajectory rather than by current weight alone.

Changes in body weight may affect specific interpersonal relationships in distinctive ways. For example, family therapy theories suggest that an obese child or adolescent plays a distinctive role in the family. The child's obesity may be used to distract attention from other family tensions; weight loss by the child may create excessive strain for the family because it disrupts established patterns of equilibrium (Rickarby 1981). Family members may go so far as to criticize and sabotage attempts at weight loss by the overweight child in an attempt to maintain stabil- ity in their relationships (Blank et al. 1981; Ganley 1986).

Changes in weight also may affect the quality of one's marital relationship (see Sobal, Rauschenbach, and Frongillo 1995, 2003). Individuals tend to date and marry romantic partners who are similar in their level of physical attractiveness (Margolin and White 1987; Nevid 1984). Yet if one partner gains considerable weight during the course of the marriage, this change could lead to loss of sexual interest and could increase marital strain (Margolin and White 1987). Weight loss, especially among wives, also may create marital strain: husbands may feel threatened if their formerly overweight wives lose weight and thus become attractive to other men (Stuart and Jacobson 1987). To explore the links between weight trajectories and relationship quality, we examine whether the relationship between body weight and relationship quality is conditional upon one's BMI in young adulthood (age 21). Although weight fluctuates during childhood, most studies show that body weight during late adolescence and young adulthood is a powerfol predictor of both adult weight (Ferraro and Kelley-Moore 2003) and body image and self-concept (Wardle, Waller, and Fox 2002).

\section{Identifying Pathways Between Body Weight and Interpersonal Relationships}

The final objective of our research is to evaluate possible reasons why body weight may be associated with positive and negative aspects of interpersonal relationships in adulthood. One possible explanation for an observed statistical association is that both weight and the quality of one's adult relationships are a consequence of childhood environment and relationships. Multiple studies document that difficulties in early life, including parental neglect and criticism, maternal depression, and family disorganization, may increase the likelihood of becoming obese both in childhood and in the longer term (Christoffel and Forsyth 1989; Costanzo and Woody 1985; Lissau and Sorensen 1994). Early obesity is associated with both problematic parent-child relationships (e.g., Banis et al. 1988) and childhood and adolescent behavioral problems (Lumeng et al. 2003). 
Problematic relationships in childhood and adolescence, in turn, may have long-term consequences for the ability to form and sustain supportive, warm relationships (Weiss 1991). To investigate the possibility that the observed association between adult body weight and interpersonal relationships is spurious, we evaluate whether the association between adult BMI and relationship quality persists after we control for the quality of the early relationship with parents.

We also explore whether the association between body weight and the quality of one's relationships reflects the impact of obesity on daily interactions, activities, and practices. Stigmatized identities that are particularly "obtrusive" and that interfere with the normal flow of interaction may be especially problematic for the quality of interpersonal relationships (Goffman 1963). Specifically, obese persons often structure their daily interactions around efforts to lose or maintain weight, or may find that their daily activities and routines are impeded by their extreme weight. Activities such as dieting or binge eating may create difficulties for interpersonal relationships. Dieting, particularly unsuccessful dieting, is associated with depression among obese persons (Ross 1994) and also may create strain for significant others as they try to accommodate the obese person's preferences and routines (Barbarin and Tirado 1984; Doherty and Harkaway 1990).

Obesity that impedes management of daily responsibilities or impairs one's physical abilities also may create interpersonal strain. Persons who are even moderately overweight suffer a greater risk of developing health conditions including coronary heart disease, diabetes, high blood pressure, and certain forms of cancer, particularly hormone-dependent cancers (Van Itallie 1985; WHO 1998). Significant others may resent their role as caretakers and helpmates to obese persons who face limitations in performing basic activities of daily life, such as climbing stairs or running errands (for a review, see Weihs, Fisher, and Baird 2002). More generally, the "minor failings" or behavioral adjustments evidenced by obese persons may be interpreted as a direct expression of their stigmatized identities, and thus may create difficulties in interactions with significant others (Goffman 1963:15). Therefore we explore the extent to which the association between adult weight and the quality of interpersonal relationships attenuates when we control three aspects of weightrelated daily activities and functioning: weight cycling, dieting, and functional limitations.

In sum, we investigate the extent to which body weight affects both positive and negative aspects of relationships with family, friends, spouses, and coworkers; whether the association between body weight and relationship quality is contingent upon one's sociodemographic characteristics and young adult body weight; and the extent to which the links between body weight and relationship quality reflect aspects of body weight that intrude upon daily interactions with significant others. Answers to these questions are important for understanding the psychosocial well-being of obese and overweight adults, who currently account for nearly twothirds of the adult population in the United States.

-Madison

\section{METHODS}

Sample

The National Survey of Midlife Development in the United States (MIDUS) is a national multistage probability sample of noninstitutionalized English-speaking adults ages 25 to 74, selected from working telephone banks in the coterminous United States. A telephone interview and a mail questionnaire were administered in 1995-1996. In the first stage, households were selected via random-digit dialing. Disproportionate stratified sampling was used at the second stage to select respondents. The sample was stratified by age and gender; males and persons age 65 to 74 were oversampled. ${ }^{2}$ The total MIDUS sample includes

2 The analyses presented here are based on the unweighted sample. Our results were virtually identical when we used the weighted data. The sample weight adjusts for unequal probabilities of household selection and of respondent selection within households. It also poststratifies the sample to match October 1995 Current Population Survey proportions of adults living in metropolitan areas and in regions 
4,242 adults (2,155 men and 2,087 women). This analysis is limited to the 3,656 persons (1,832 men and 1,824 women) who completed the mail questionnaire, including questions on social relationships. The response rate for the self-administered mail questionnaire is 87 percent. Because of the moderate rate of nonresponse, caution is advised in extrapolating the results to the total population in the same age range (for further details on the MIDUS study, see Brim, Ryff, and Kessler 2004).

\section{Variables}

Dependent variables. We consider positive and negative aspects of relationships with one's spouse, family members other than one's spouse, and friends. We consider only positive interactions with coworkers because the MIDUS does not evaluate problematic relationships with coworkers. Positive/supportive relationships with spouse, family, and friends are measured with four items that ask respondents how much each target person or persons (1) realiy care(s) about you; (2) understand(s) the way you feel about things; and (3) can be relied on for help if you have a serious problem; as well as (4) how much you can open up to him or her if you need to talk about your worries. Positive/supportive relationships with coworkers are evaluated with two items: (1) How often do you get help and support from your coworkers? and (2) How often are your coworkers willing to listen to your workrelated problems? The intra-item reliabilities (Cronbach's alpha) are .87 for spouses, .84 for family, .88 for friends, and .73 for coworkers.

Negative/problematic relationships are assessed with four items that ask respondents how much each such person or persons (1) make(s) too many demands on you; (2) criticize(s) you; (3) let(s) you down when you are counting on him or her; and (4) get(s) on your nerves. The intra-item reliabilities (Cronbach's alpha) are .81 for spouses, .84 for family, and .79 for friends. Response categories range from 1 (not at all) to 4 (a lot). Scale scores are the average of one's respons-

(northeast, midwest, south, and west) of the United States. es; higher scores represent higher levels of a relationship attribute. Each of the relationship quality scores is standardized for ease of interpretation and comparison across measures; each scale has a mean of zero and a standard deviation of $1 .^{3}$

Independent variables. Body mass index (BMI) is the key independent variable of our analysis. All MIDUS participants were asked to report their weight and height. BMI is calculated by the formula in which BMI equals weight in kilograms divided by height in meters squared. Continuous BMI scores were recoded into six categories based on cutpoints defined by National Heart, Lung, and Blood Institute (NHLBI) guidelines (1998). The six categories are underweight (BMI below 18.5), normal (BMI 18.5 to 24.9), overweight (BMI 25 to 29.9), obese class I (BMI 30 to 34.9), obese class II (BMI 35 to 39.9), and obese class III (BMI 40 and above). ${ }^{4}$ The latter two categories are combined in this analysis because of the small number of cases in the obese class III category. ${ }^{5}$

sconsin-Madison

${ }^{3}$ In general, respondents reported higher raw scores on positive than on negative relations scales. The means and standard deviations for the relationship quality measures, based on the original metrics, are as follows: positive relations with friends, $M=$ $3.22, \mathrm{sd}=.67$; negative relations with friends, $M=1.95$, $\mathrm{sd}=.52$; positive relations with spouse, $M=3.55$, sd $=.60$; negative relations with spouse, $M=2.18$, $\mathrm{sd}=.64$; positive relations with family, $M=3.41$, sd =.63; negative relations with family, $M=2.12$, $\mathrm{sd}=.63$; positive relations with coworkers, $M=3.41$, sd =.63.

"Obese III includes "morbidly obese" persons with a heightened risk of one or more obesity-related health conditions that may result in physical disability or death (NHLBI 1998).

${ }^{5}$ In preliminary analyses, we also estimated all OLS regression analyses using two alternative measures of BMI: a continuous measure of BMI scores ranging from roughly 15 to 55 , and a quadratic measure - that is, a continuous measure of BMI and a continuous measure of BMI squared. Substantive results supported the analyses presented here. The quadratic term was not statistically significant; this finding suggests a linear relationship between BMI and the quality of the relationship with family members. Although our substantive findings were consistent in models using the continuous and categorical BMI indicators, the model fit statistics (adjusted $R^{2}$ values) suggested that models with the categorical indicator fit the data better. As a result, we present results for the categorical BMI models only. Complete models are available from the first author. 
We recognize that self-reported height and weight measures may be biased: some studies show that individuals tend to underestimate their weight and overestimate their height (e.g., Bowman and DeLuca 1992). Other researchers counter that self-reported weights are correlated highly with scale weights (Palta et al. 1982; Stunkard and Albaum 1981). Although obese persons may be particularly likely to underestimate their weight, the bias introduced by using selfreport data is generally considered "small and inconsequential" (Palta et al. 1982:230). We also recognize that persons who are especially troubled by their weight may not report their weight data; thus we include a separate dichotomous variable indicating those persons who did not report either their height or their weight, and whose BMI thus cannot be calculated.

Demographic and socioeconomic status characteristics. Demographic and socioeconomic status characteristics are controlled in the multivariate analyses because they are important correlates of BMI (Flegal et al. 2002; Sobal and Stunkard 1989), and also may affect the quality of one's personal relationships (Antonucci 2001). Demographic characteristics are sex $(1=$ female; $0=$ male $)$, race ( 1 = black; 0 = other), age (continuous measure ranging from 25 to 74 ), marital status (categorical variables indicate persons who are never married and persons who are formerly married; currently married is the reference group), and parental status ( 1 = has any children; 0 = does not have children). Models predicting marital quality do not adjust for marital status because only currently married persons are asked the marital quality questions. Marital duration (in years) is controlled in models predicting marital quality.

Socioeconomic status indicators include educational attainment and employment status. Years of completed education are recoded into the following categories: less than 12 years, 12 years (reference category), 13 to 15 years, and 16 or more years. Employment status is a dichotomous variable indicating that one is not currently employed. Models predicting quality of coworker relationships do not adjust for employment status because only currently employed persons were asked to evaluate these relationships.
Finally, we control for both physical and emotional health; both potentially may confound the relationship between BMI and relationship quality. Self-rated physical health is evaluated with the question "In general, would you say your physical health is excellent, very good, good, fair, or poor?" Responses are recoded into a dichotomous variable in which 1 represents fair or poor health, and 0 represents the reference group of good or better. Psychological distress $($ alpha $=.87)$ is assessed with a six-item scale asking respondents how often during the past 30 days they felt nervous; restless or fidgety; hopeless; that everything was an effort; worthless; and so sad that nothing could cheer them up. Scale scores are the average of the six items; higher scores reflect higher levels of psychological distress.

\section{Potential Mediator and Moderator Variables}

The two main objectives of our analysis are to evaluate whether the effect of body weight on personal relationships is contingent upon demographic characteristics and early body weight, and to identify those factors which may explain the association between body weight and the quality of one's personal relationships. To achieve these aims, we first evaluate whether the effect of BMI on evaluations of one's relationships differs significantly by gender, race, age, and socioeconomic status; we operationalize socioeconomic status with a broad indicator of one's current (or most recent) occupational standing $(1=$ professional or managerial occupation; $0=$ lower white- or blue-collar occupation).

We also evaluate whether the effect of current BMI is moderated by youthful BMI, given that changes in one's weight over the life course may have important implications for one's relationships. We evaluate early body weight with the question "About how much did you weigh when you were 21 years old." We calculated BMI scores for weight at age 21 , and recoded these scores into a simple dichotomous variable indicating those who were normal/underweight versus overweight or above (reference category). We used a BMI of 25 as the cutpoint because the Centers for Disease Control (CDC) have 
determined that children and adolescents with a BMI of roughly 25 are "at risk for overweight" (CDC 2000).

We evaluate two sets of variables as possible explanations for an observed relationship between BMI and relationship quality: early parental relationships and indicators of weight intrusiveness. Early relationships are evaluated with two separate indicators: "How would you rate your relationship with your mother (or the woman who raised you) during the years you were growing up?" and "How would you rate your relationship with your father (or the man who raised you) during the years you were growing up?" Scores range from 1 (poor) to 5 (excellent).

We also consider three aspects of weight intrusiveness: dieting, weight cycling, and functional limitations. Dieting is a dichotomous variable equal to 1 for positive responses to the question "Have you used special diets in the past 12 months, either to treat a physical health problem, to treat an emotional or personal problem, to maintain or enhance your wellness, or to prevent the onset of illness?" Weight cycling is assessed with the question "During your lifevime, about how many times have you lost 10 pounds or more?" (excluding women after childbirth). Responses ranged from 0 to 100 ; we top-coded this measure at 10 because 90 percent of all respondents said that they had experienced 10 or fewer weight fluctuations during their life. This simple measure is used widely in studies of weight cycling (e.g., Bartlett, Wadden, and Vogt 1996). Functional limitations are measured with the Instrumental Activities of Daily Living (IADL) Scale, which assesses one's difficulty in performing selected activities of daily life. Respondents are asked "How much does your health limit you in doing each of the following? (a) lifting or carrying groceries; (b) climbing several flights of stairs; (c) bending, kneeling, or stooping; (d) walking more than a mile; (e) walking several blocks; (f) vigorous activity (e.g., lifting heavy objects); and (g) moderate activity (e.g., vacuuming)." Response categories range from 1 (not at all) to 4 (a lot). Scale scores reflect the average response across the seven items, where higher scores reflect greater functional impairment.

\section{Analytic Plan}

The research plan has three steps. First, we compare the quality of one's social relationships, and the demographic, socioeconomic, and health characteristics among persons classified as underweight, normal weight, overweight, obese I, and obese II/III. Second, we evaluate the extent to which BMI affects one's evaluations of relationships with spouse, family, friends, and coworkers, after controlling for potential confounding factors including demographic characteristics, socioeconomic status, and physical and emotional well-being. Third, we examine the extent to which the association between BMI and relationship quality varies on the basis of one's gender, race, age, social class, and early (age 21) BMI. Finally, we evaluate whether the statistical association between BMI and relationship quality is mediated (or confounded) by early parental relationships and weight intrusiveness.

\section{RESULTS}

\section{Bivariate Anolysis}

Table 1 presents descriptive statistics (means or proportions, and standard deviations) for all variables used in the analysis, by BMI category. We conducted two-tailed $t$ tests to evaluate whether each weight category differs significantly from the "normal" category. Roughly 37 percent of the MIDUS sample is overweight (BMI 25 to 29.9); an additional 22 percent is classified as obese $(\mathrm{BMI} \geq 30)$. These proportions are similar to national estimates showing that 18 to 25 percent of the U.S. population is obese, while 50 to 60 percent is overweight or obese (Flegal et al. 2002; Mokdad et al. 1999). Nearly 80 percent of respondents report that they were of normal weight or underweight at age 21; this figure is consistent with national estimates that 20 percent of American adolescents have a BMI of 25 or higher (Ogden et al. 2002).

The bivariate analyses reveal that very obese persons (obese II/III) report significantly worse relationships with friends and family members than do normal-weight persons, although they do not differ significantly in their relationships with spouses or cowork- 
Table 1. Means and Proportions, Relationship Quality, Demographic, Socioeconomic, Health, and Life Course Characteristics by Body Mass Index (BMI), Midlife in the United States (MIDUS), 1995

\begin{tabular}{|c|c|c|c|c|c|c|c|}
\hline & $\begin{array}{c}\text { Total } \\
\text { Sample }\end{array}$ & $\begin{array}{l}\text { Under- } \\
\text { weight } \\
(<18.5)\end{array}$ & $\begin{array}{c}\text { Normal } \\
(18.5- \\
24.9)\end{array}$ & $\begin{array}{l}\text { Over- } \\
\text { weight } \\
(25- \\
29.9)\end{array}$ & $\begin{array}{l}\text { Obese I } \\
(30- \\
34.9)\end{array}$ & $\begin{array}{l}\text { Obese } \\
\text { II/III } \\
(35+)\end{array}$ & $\begin{array}{l}\text { Did Not } \\
\text { Report }\end{array}$ \\
\hline \multicolumn{8}{|l|}{ Social Support } \\
\hline $\begin{array}{l}\text { Negative } \\
\text { interactions, } \\
\text { family members }\end{array}$ & $\begin{array}{l}0 \\
(1.0)\end{array}$ & $\begin{array}{c}.08 \\
(1.01)\end{array}$ & $\begin{array}{l}-.03 \\
(.99)\end{array}$ & $\begin{array}{l}-.06 \\
(.99)\end{array}$ & $\begin{array}{c}-.01 \\
(.98)\end{array}$ & $\begin{array}{l}.29 * * * \\
(1.04)\end{array}$ & $\begin{array}{l}.19 * * * \\
(1.1)^{2}\end{array}$ \\
\hline $\begin{array}{l}\text { Positive } \\
\text { interactions, } \\
\text { family members }\end{array}$ & $\begin{array}{l}0 \\
(1.0)\end{array}$ & $\begin{array}{c}.06 \\
(.99)\end{array}$ & $\begin{array}{c}.03 \\
(1.02)\end{array}$ & $\begin{array}{c}.01 \\
(1.03)\end{array}$ & $\begin{array}{c}-.01 \\
(.98)\end{array}$ & $\begin{array}{c}-.14^{*} \\
(1.09)\end{array}$ & $\begin{array}{c}-.04 \\
(1.02)\end{array}$ \\
\hline $\begin{array}{l}\text { Negative } \\
\text { interactions, } \\
\text { spouse }\end{array}$ & $\begin{array}{c}0 \\
(1.0)\end{array}$ & $\begin{array}{c}.20 \\
(1.03)\end{array}$ & $\begin{array}{l}-.03 \\
(.98)\end{array}$ & $\begin{array}{c}-.01 \\
(.99)\end{array}$ & $\begin{array}{c}-.02 \\
(1.03)\end{array}$ & $\begin{array}{c}.12 \\
(1.04)\end{array}$ & $\begin{array}{c}-.02 \\
(1.03)\end{array}$ \\
\hline $\begin{array}{l}\text { Positive } \\
\text { interactions, } \\
\text { spouse }\end{array}$ & $\begin{array}{l}0 \\
(1.0)\end{array}$ & $\begin{array}{c}-.31 * \\
(1.35)\end{array}$ & $\begin{array}{c}.03 \\
(1.21)\end{array}$ & $\begin{array}{c}.03 \\
(.96)\end{array}$ & $\begin{array}{c}-.01 \\
(1.03)\end{array}$ & $\begin{array}{c}-.12 \\
(1.03)\end{array}$ & $\begin{array}{c}-.05 \\
(1.02)\end{array}$ \\
\hline $\begin{array}{l}\text { Negative } \\
\text { interactions, } \\
\text { friends }\end{array}$ & $\begin{array}{l}0 \\
(1.0)\end{array}$ & $\begin{array}{c}.09 \\
(1.05)\end{array}$ & $\begin{array}{c}-.02 \\
(1.00)\end{array}$ & $\begin{array}{c}-.01 \\
(.95)\end{array}$ & $\begin{array}{c}-.04 \\
(1.04)\end{array}$ & $\begin{array}{c}.11 * \\
(1.12)\end{array}$ & $\begin{array}{c}.10 \\
(.96)\end{array}$ \\
\hline $\begin{array}{l}\text { Positive } \\
\text { interactions, } \\
\text { friends }\end{array}$ & $\begin{array}{l}0 \\
(1.0)\end{array}$ & $\begin{array}{c}-.01 \\
(1.15)\end{array}$ & $\begin{array}{c}.07 \\
(1.00)\end{array}$ & $\begin{array}{c}-.01 * \\
(.95)\end{array}$ & $\begin{array}{l}-.08 * * \\
(1.04)\end{array}$ & $\begin{array}{c}-.07 * \\
(1.12)\end{array}$ & $\begin{array}{l}-.02 \\
(.96)\end{array}$ \\
\hline $\begin{array}{l}\text { Positive } \\
\text { interactions, } \\
\text { coworkers }\end{array}$ & $\begin{array}{l}0 \\
(1.0)\end{array}$ & $\begin{array}{c}.09 \\
(.89)\end{array}$ & $\begin{array}{l}-.01 \\
(.97)\end{array}$ & $\begin{array}{c}-.02 \\
(1.01)\end{array}$ & $\begin{array}{c}.04 \\
(1.04)\end{array}$ & $\begin{array}{c}-.02 \\
(1.01)\end{array}$ & $\begin{array}{c}.05 \\
(1.01)\end{array}$ \\
\hline \multicolumn{8}{|l|}{ Demographics } \\
\hline $\begin{array}{l}\text { Sex } \\
\quad(1=\text { female })\end{array}$ & $\begin{array}{c}.05 \\
(.50)\end{array}$ & $\begin{array}{l}\text { U.79** } \\
(.41)\end{array}$ & $\begin{array}{l}y .60 \mathrm{ii} \\
22(.49)\end{array}$ & 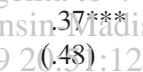 & $\begin{array}{l}(.49) \\
(44 * *\end{array}$ & $\begin{array}{l}.63 \\
(.48)\end{array}$ & $\begin{array}{c}.60 \\
(.49)\end{array}$ \\
\hline $\begin{array}{l}\text { Race } \\
\qquad(1=\text { black })\end{array}$ & $\begin{array}{l}.06 \\
(.24)\end{array}$ & $\begin{array}{l}.03 \\
(.16)\end{array}$ & $\begin{array}{c}.04 \\
(.20)\end{array}$ & $\begin{array}{l}.06^{*} \\
(.24)\end{array}$ & $\begin{array}{l}.04 * * * \\
(.20)\end{array}$ & $\begin{array}{l}.12 * * * \\
(.32)\end{array}$ & $\begin{array}{l}.10^{* *} \\
(.29)\end{array}$ \\
\hline Age (in years) & $\begin{array}{c}47.04 \\
(13.25)\end{array}$ & $\begin{array}{c}40.92 * \\
(13.05)\end{array}$ & $\begin{array}{c}44.99 \\
(13.41)\end{array}$ & $\begin{array}{l}48.13 * * * \\
(13.52)\end{array}$ & $\begin{array}{l}49.8^{* * * *} \\
(12.01)\end{array}$ & $\begin{array}{l}47.56^{* * *} \\
(11.91)\end{array}$ & $\begin{array}{l}46.1 \\
(13.15)\end{array}$ \\
\hline $\begin{array}{l}\text { Currently } \\
\text { married }\end{array}$ & $\begin{array}{c}.63 \\
(.48)\end{array}$ & $\begin{array}{l}.45^{*} \\
(.50)\end{array}$ & $\begin{array}{c}.59 \\
(.49)\end{array}$ & $\begin{array}{l}.67 * * * \\
(.47)\end{array}$ & $\begin{array}{l}.67 * * * \\
(.47)\end{array}$ & $\begin{array}{c}.62 \\
(.49)\end{array}$ & $\begin{array}{c}.59 \\
(.49)\end{array}$ \\
\hline $\begin{array}{l}\text { Separated/ } \\
\text { divorced }\end{array}$ & $\begin{array}{l}.18 \\
(.38)\end{array}$ & $\begin{array}{l}.30 * \\
(.46)\end{array}$ & $\begin{array}{l}.20 \\
(.39)\end{array}$ & $\begin{array}{l}.16^{*} \\
(.37)\end{array}$ & $\begin{array}{l}.18 \\
(.38)\end{array}$ & $\begin{array}{l}.17 \\
(.37)\end{array}$ & $\begin{array}{l}.15 \\
(.35)\end{array}$ \\
\hline Widowed & $\begin{array}{l}.13 \\
(.34)\end{array}$ & $\begin{array}{l}.19 \\
(.39)\end{array}$ & $\begin{array}{l}.16 \\
(.36)\end{array}$ & $\begin{array}{l}.11^{* * * *} \\
(.31)\end{array}$ & $\begin{array}{l}.09 * * * \\
(.29)\end{array}$ & $\begin{array}{l}.14 \\
(.35)\end{array}$ & $\begin{array}{l}.18 \\
(.38)\end{array}$ \\
\hline Never married & $\begin{array}{c}.13 \\
(.34)\end{array}$ & $\begin{array}{l}.19 \\
(.39)\end{array}$ & $\begin{array}{l}.16 \\
(.36)\end{array}$ & $\begin{array}{l}.11 * * * \\
(.31)\end{array}$ & $\begin{array}{l}.09 * * * \\
(.29)\end{array}$ & $\begin{array}{l}.14 \\
(.35)\end{array}$ & $\begin{array}{l}.18 \\
(.38)\end{array}$ \\
\hline $\begin{array}{l}\text { Duration of } \\
\text { current } \\
\text { marriage or } \\
\text { cohabiting } \\
\text { relationship } \\
\text { (in years) }\end{array}$ & $\begin{array}{c}21.78 \\
(14.26)\end{array}$ & $\begin{array}{c}18.47 \\
(12.99)\end{array}$ & $\begin{array}{c}19.91 \\
(13.90)\end{array}$ & $\begin{array}{l}22.33^{* * * *} \\
(14.6)\end{array}$ & $\begin{array}{l}23.61 * * * \\
(14.06)\end{array}$ & $\begin{array}{l}23.14^{* * * *} \\
(13.99)\end{array}$ & $\begin{array}{l}23.36^{* * *} \\
(14.23)\end{array}$ \\
\hline $\begin{array}{l}\text { Has any } \\
\text { children }\end{array}$ & $\begin{array}{l}0.81 \\
(.39)\end{array}$ & $\begin{array}{l}.74 \\
(.44)\end{array}$ & $\begin{array}{l}.77 \\
(.42)\end{array}$ & $\begin{array}{l}.84 * * * \\
(.37)\end{array}$ & $\begin{array}{l}.86 * * * \\
(.35)\end{array}$ & $\begin{array}{l}.82 \\
(.39)\end{array}$ & $\begin{array}{l}.82 \\
(.38)\end{array}$ \\
\hline \multicolumn{8}{|l|}{ Socioeconomic Status } \\
\hline $\begin{array}{l}\text { Less than } 12 \\
\text { years of } \\
\text { education }\end{array}$ & $\begin{array}{c}.09 \\
(.29)\end{array}$ & $\begin{array}{l}.08 \\
(.28)\end{array}$ & $\begin{array}{l}.07 \\
(.26)\end{array}$ & $\begin{array}{c}.09 \\
(.28)\end{array}$ & $\begin{array}{l}.14 * * * \\
(.34)\end{array}$ & $\begin{array}{c}.09 \\
(.29)\end{array}$ & $\begin{array}{l}.11 * \\
(.31)\end{array}$ \\
\hline $\begin{array}{l}12 \text { years of } \\
\text { education }\end{array}$ & $\begin{array}{l}.28 \\
(.45)\end{array}$ & $\begin{array}{c}.24 \\
(.43)\end{array}$ & $\begin{array}{l}.24 \\
(.43)\end{array}$ & $\begin{array}{l}.30 * * \\
(.46)\end{array}$ & $\begin{array}{l}.31 * * \\
(.46)\end{array}$ & $\begin{array}{l}.35 * * * \\
(.48)\end{array}$ & $\begin{array}{l}.30 \\
(.46)\end{array}$ \\
\hline $\begin{array}{l}\text { 13-15 years of } \\
\text { education }\end{array}$ & $\begin{array}{l}.30 \\
(.46)\end{array}$ & $\begin{array}{l}.36 \\
(.49)\end{array}$ & $\begin{array}{l}.31 \\
(.46)\end{array}$ & $\begin{array}{l}.28 \\
(.45)\end{array}$ & $\begin{array}{l}.30 \\
(.46)\end{array}$ & $\begin{array}{l}.33 \\
(.47)\end{array}$ & $\begin{array}{c}.31 \\
(.46)\end{array}$ \\
\hline $\begin{array}{l}16+\text { years of } \\
\text { education }\end{array}$ & $\begin{array}{l}.33 \\
(.47)\end{array}$ & $\begin{array}{l}.31 \\
(.47)\end{array}$ & $\begin{array}{l}.38 \\
(.49)\end{array}$ & $\begin{array}{l}.33 * \\
(.47)\end{array}$ & $\begin{array}{l}.25^{* * *} \\
(.45)\end{array}$ & $\begin{array}{l}.23 * * * \\
(.42)\end{array}$ & $\begin{array}{l}.29 * * * \\
(.46)\end{array}$ \\
\hline $\begin{array}{l}\text { Not currently } \\
\text { employed }\end{array}$ & $\begin{array}{l}.28 \\
(.45)\end{array}$ & $\begin{array}{l}.43 \\
(.48)\end{array}$ & $\begin{array}{l}.28 \\
(.45)\end{array}$ & $\begin{array}{l}.28 \\
(.45)\end{array}$ & $\begin{array}{l}.27 \\
(.45)\end{array}$ & $\begin{array}{l}.32 \\
(.47)\end{array}$ & $\begin{array}{l}.32 \\
(.47)\end{array}$ \\
\hline
\end{tabular}




\begin{tabular}{|c|c|c|c|c|c|c|c|}
\hline & $\begin{array}{c}\text { Total } \\
\text { Sample }\end{array}$ & $\begin{array}{l}\text { Under- } \\
\text { weight } \\
(<18.5)\end{array}$ & $\begin{array}{c}\text { Normal } \\
(18.5- \\
24.9)\end{array}$ & $\begin{array}{l}\text { Over- } \\
\text { weight } \\
(25- \\
29.9)\end{array}$ & $\begin{array}{c}\text { Obese I } \\
(30- \\
34.9)\end{array}$ & $\begin{array}{l}\text { Obese } \\
\text { II/III } \\
(35+)\end{array}$ & $\begin{array}{l}\text { Did Not } \\
\text { Report }\end{array}$ \\
\hline \multicolumn{8}{|l|}{ Current Well-being } \\
\hline $\begin{array}{l}\text { Psychological } \\
\text { distress }\end{array}$ & $\begin{array}{c}3.35 \\
(1.53)\end{array}$ & $\begin{array}{c}3.66 \\
(1.36)\end{array}$ & $\begin{array}{c}3.43 \\
(1.51)\end{array}$ & $\begin{array}{l}3.31^{*} \\
(1.6)\end{array}$ & $\begin{array}{l}3.21 * * \\
(1.57)\end{array}$ & $\begin{array}{c}3.44 \\
(1.42)\end{array}$ & $\begin{array}{c}3.37 \\
(1.48)\end{array}$ \\
\hline $\begin{array}{l}\text { Self-rated } \\
\text { health, } \\
\text { fair/poor }\end{array}$ & $\begin{array}{l}.15 \\
(.36)\end{array}$ & $\begin{array}{r}.20^{*} \\
(.41)\end{array}$ & $\begin{array}{c}.11 \\
(.31)\end{array}$ & $\begin{array}{c}.13 \\
(.34)\end{array}$ & $\begin{array}{l}.21 * * * \\
(.41)\end{array}$ & $\begin{array}{l}.30 * * * \\
(.46)\end{array}$ & $\begin{array}{c}.16 \\
(.36)\end{array}$ \\
\hline \multicolumn{8}{|l|}{ Life Course Variables } \\
\hline $\begin{array}{l}\text { BMI at age 21: } \\
\text { normal/ } \\
\text { underweight }\end{array}$ & $\begin{array}{l}.79 \\
(.41)\end{array}$ & $\begin{array}{l}1.0 \\
(.00)\end{array}$ & $\begin{array}{l}.96 \\
(.20)\end{array}$ & $\begin{array}{l}.79 * * * \\
(.41)\end{array}$ & $\begin{array}{l}.56 * * * \\
(.50)\end{array}$ & $\begin{array}{l}.37 * * * \\
(.48)\end{array}$ & $\begin{array}{l}.92 * \\
(.28)\end{array}$ \\
\hline $\begin{array}{l}\text { Quality of } \\
\text { relationship } \\
\text { with mother } \\
\text { when growing } \\
\text { up }\end{array}$ & $\begin{array}{c}3.81 \\
(1.10)\end{array}$ & $\begin{array}{c}3.57 \\
(1.22)\end{array}$ & $\begin{array}{c}3.74 \\
(1.13)\end{array}$ & $\begin{array}{l}3.88 * * \\
(1.07)\end{array}$ & $\begin{array}{r}3.88^{*} \\
(1.04)\end{array}$ & $\begin{array}{l}3.84 \\
(1.9)\end{array}$ & $\begin{array}{r}3.69 \\
(1.6)\end{array}$ \\
\hline $\begin{array}{l}\text { Quality of } \\
\text { relationship } \\
\text { with father } \\
\text { when growing } \\
\text { up }\end{array}$ & $\begin{array}{c}3.43 \\
(1.18)\end{array}$ & $\begin{array}{c}3.66 \\
(1.20)\end{array}$ & $\begin{array}{c}3.39 \\
(1.21)\end{array}$ & $\begin{array}{c}3.45 \\
(1.13)\end{array}$ & $\begin{array}{c}3.45 \\
(1.21)\end{array}$ & $\begin{array}{c}3.54 \\
(1.24)\end{array}$ & $\begin{array}{l}3.25 \\
(1.22)\end{array}$ \\
\hline \multicolumn{8}{|c|}{ Health and Health Behavior Consequences } \\
\hline $\begin{array}{l}\text { Limitations } \\
\text { with }\end{array}$ & $\begin{array}{l}1.59 \\
(.79)\end{array}$ & $\begin{array}{l}1.66^{* * * *} \\
(.79)\end{array}$ & $\begin{array}{l}1.38 \\
(.63)\end{array}$ & $\begin{array}{l}1.55 * * * \\
(.76)\end{array}$ & $\begin{array}{l}1.80 * * * \\
(.86)\end{array}$ & $\begin{array}{l}2.13 * * * \\
(.89)\end{array}$ & $\begin{array}{l}1.66 * * * \\
(.87)\end{array}$ \\
\hline $\begin{array}{l}\text { intermediate } \\
\text { daily living } \\
\text { activities }\end{array}$ & & $\begin{array}{r}\text { Deli } \\
\text { Universi } \\
\text { Tue, }\end{array}$ & $\begin{array}{l}\text { ered by } \\
\text { y of Wi: } \\
2 \text { Dec } 2\end{array}$ & $\begin{array}{l}\text { nta to : } \\
\text { sin-Mad } \\
20: 51: 12\end{array}$ & son & & \\
\hline $\begin{array}{l}\text { Has eaten a } \\
\text { special diet } \\
\text { in the past } 12 \\
\text { months for } \\
\text { health reasons }\end{array}$ & $\begin{array}{c}.12 \\
(.32)\end{array}$ & $\begin{array}{c}.08 \\
(.28)\end{array}$ & $\begin{array}{c}.09 \\
(.29)\end{array}$ & $\begin{array}{c}.11 \\
(.31)\end{array}$ & $\begin{array}{l}.15^{* * *} \\
(.36)\end{array}$ & $\begin{array}{l}.21 * * * \\
(.41)\end{array}$ & $\begin{array}{c}.12 \\
(.32)\end{array}$ \\
\hline $\begin{array}{l}\text { Number of } \\
\text { times } \\
\text { lost/gained } 10 \\
\text { pounds }\end{array}$ & $\begin{array}{c}3.26 \\
(3.36)\end{array}$ & $\begin{array}{c}1.77 \\
(2.48)\end{array}$ & $\begin{array}{c}2.13 \\
(2.81)\end{array}$ & $\begin{array}{l}2.99 * * \\
(3.07)\end{array}$ & $\begin{array}{l}4.69 * * * \\
(3.41)\end{array}$ & $\begin{array}{l}3.62 * * * \\
(3.53)\end{array}$ & $\begin{array}{l}4.42 * * * \\
(4.05)\end{array}$ \\
\hline$N$ & 3,656 & 74 & 1,224 & 1,350 & 547 & 282 & 179 \\
\hline$\%$ & 100 & 2 & 33.5 & 36.9 & 15 & 7.7 & 4.9 \\
\hline
\end{tabular}

Notes: $N=3,656$. Two-tailed $t$-tests were conducted to evaluate significant differences. The reference category is "normal weight." All relationship quality measures are standardized, and thus have a mean of 0 and a standard deviation of 1 .

$* p \leq .05 ; * * p \leq .01 ; * * * p \leq .001$

ers. Compared to normal-weight persons, persons in the obese II/III category report significantly higher levels of strain in their relationships with family members (.29 versus $-.06, p \leq .001)$ and friends (.11 versus -.02 , $p \leq .05)$. Highly obese persons also report significantly less emotional support from family members $(-.14$ versus $.03, p \leq .05)$ and friends $(-.07$ versus $.07, p \leq .05)$. Both overweight and obese I persons report significantly less positive support from friends than do normal-weight persons. Underweight persons differ from normal-weight persons in only one relationship dimension: they report significantly lower levels of positive interaction with their spouses $(-.31$ versus $.03, p \leq .05)$. Persons who did not provide information on their body weight (or height) report elevated levels of conflict with family members (.19 versus $-.03, p \leq .01){ }^{6}$

${ }^{6}$ The 179 sample members who did not provide either height or weight data are significantly more likely than normal-weight respondents to report that they have experienced some form of interpersonal or institutional discrimination due to their weight. Consequently we believe that the "missing"-weight 
Although obesity is associated with the quality of one's family relationships, it is not associated strongly with one's family roles. Neither marital nor parental status is associated systematically with BMI. Although overweight and obese persons report longer marriages than do normal-weight persons, this probably reflects the strong correlation between BMI and age. Consistent with past studies of the demographic correlates of obesity, we find that African Americans and persons in poor physical health are overrepresented among persons classified as obese II/III. Obesity is related inversely to socioeconomic status: the proportion of respondents with at least a college degree declines monotonically as weight increases beyond the "normal" category.

The quality of one's childhood relationship with parents is not related systematically to current body weight. Current BMI, however, is related strongly to early BMI: the proportion of persons whose weight was classified as "normal" or "underweight" at age 21 declines across the current weight categories. While 96 percent of currently "normal"-weight persons also were of normal weight (or underweight) at age 21 , only 56 percent of obese I persons and 37 percent of persons now classified as obese II/III reported this $(p \leq .001)$. Daily health practices and limitations are linked strongly to BMI: obese persons are significantly more likely than normal-weight persons to report that they have maintained a special diet in the past 12 months $(21 \%$ versus $11 \%, p \leq .001)$. Weight fluctuations also increase as BMI increases: the average number of times a person gained (or lost) 10 pounds in his or her life ranges from one or two among underweight and normal-weight persons, to six for persons classified as highly obese. Weight also is linked strongly to health limitations: functional limitation scores are significantly higher for overweight, obese, and underweight persons than for persons of normal weight.

\section{Multivariate Analysis}

Obesity and interpersonal relationships.

persons overrepresent persons who would be classified obese or overweight. Thus the findings presented for the obese in our study may be slightly understated.
Our next objective is to explore whether the association between BMI and relationship quality persists when correlates of both obesity and interpersonal relationships are controlled. In Table 2 we present nested OLS regression models that evaluate the extent to which the gross (unadjusted) effect of BMI on relationship quality (Model 1) is explained or suppressed by demographic characteristics (Model 2), socioeconomic characteristics (Model 3), physical health (Model 4), and psychological distress (Model 5 ). The multivariate analyses confirm that $\mathrm{BMI}$ is not related significantly to the quality of one's relationship with spouse or coworkers, after controlling for possible confounding (or suppressing) factors. Although the bivariate analyses in Table 1 show that persons classified as obese II/III have significantly more negative and less positive interactions with friends $(p \leq .05)$, this relationship is no longer statistically significant after physical health and psychological distress are controlled.

Obesity, however, remains a powerful predictor of both supportive and problematic interactions with family members, even after demographic, socioeconomic status, and health characteristics are controlled. As shown by Model 5 in Table 2, persons classified as obese II/III report positive family interaction scores that are .14 standard deviation lower than normal-weight persons ( $p \leq$ $.05)$, and negative family interaction scores that are .27 standard deviation higher than normal-weight persons ( $p \leq .001)$. Moreover, persons who do not report their weight reveal highly conflicted relationships with family members, even after psychological distress levels are controlled (beta $=.26, p \leq$ .001). (Models for family relationships only are presented here; models for the five remaining outcomes are available from the first author.)

The effects of BMI across subgroups. We now explore whether the relationship between BMI and the quality of one's relationships varies by demographic and socioeconomic characteristics, as well as by one's weight at age 21 . We reestimated Model 5 presented in Table 2 for each of the seven relationship quality outcomes. In separate models, we evaluated a two-way interaction 
Table 2. Summary of Nested OLS Regression Models Estimating Effect of Body Mass Index (BMI), Demographic, Socioeconomic, and Health Characteristics on Quality of Family Relationships, MIDUS 1995

\begin{tabular}{|c|c|c|c|c|c|}
\hline & Model 1 & Model 2 & Model 3 & Model 4 & Model 5 \\
\hline & BMI Only & $\begin{array}{c}(1)+ \\
\text { Demographic } \\
\text { Character- } \\
\text { istics }\end{array}$ & $\begin{array}{c}(2)+ \\
\text { SES } \\
\text { Character- } \\
\text { istics }\end{array}$ & $\begin{array}{c}(3)+ \\
\text { Self- } \\
\text { Rated } \\
\text { Health }\end{array}$ & $\begin{array}{c}(4)+ \\
\text { Psycho- } \\
\text { logical } \\
\text { Distress }\end{array}$ \\
\hline \multicolumn{6}{|c|}{ Outcome: Positive Relationships With Family } \\
\hline Underweight & .03 & .04 & .04 & .06 & .05 \\
\hline Overweight & -.02 & -.01 & -.01 & -.01 & -.01 \\
\hline Obese I & -.03 & -.04 & -.02 & -.01 & -.01 \\
\hline Obese II/III & $-.16^{*}$ & $-.18^{* *}$ & $-.17 *$ & $-.14 *$ & $-.14 *$ \\
\hline Missing & -.08 & -.09 & -.08 & -.07 & -.08 \\
\hline Constant & .03 & .01 & -.04 & -.02 & .08 \\
\hline Adj. $R^{2}$ & .01 & .02 & .02 & .02 & .02 \\
\hline \multicolumn{6}{|c|}{ Outcome: Negative Relationships With Family } \\
\hline Underweight & .11 & .04 & .04 & .03 & .02 \\
\hline Overweight & -.02 & .05 & .06 & .06 & .06 \\
\hline Obese I & .01 & .07 & .07 & .06 & .06 \\
\hline Obese II/III & $.30 * * *$ & $.29 * * *$ & $.29 * * *$ & $.27 * * *$ & $.27 * * *$ \\
\hline Missing & $.26^{* *}$ & $.26 * *$ & $.26 * *$ & $.25^{* *}$ & $.26^{* *}$ \\
\hline Constant & -.03 & -.32 & -.34 & -.35 & -.50 \\
\hline Adj. $R^{2}$ & .01 & .04 & .04 & .04 & .05 \\
\hline
\end{tabular}

Notes: $N=3,656$. Standardized coefficients are presented. "Normal weight" is the omitted category. Demographic characteristics include age, sex, race, marital status, and parental status. SES characteristics include educational attainment and employment status.

$* p \leq .05 ; * * p \leq .01 ; * * * \leq .001$

term between each BMI category and an indicator of gender, age, race, occupation (holding an upper white-collar job versus a nonprofessional job), and BMI at age 21 (normal/underweight versus overweight or above). A statistically significant interaction term would suggest that the effect of BMI on interpersonal relationships varies on the basis of a particular personal characteristic.

Of the 35 models estimated, only one yielded both statistically significant interaction effects and main effects: the effect of BMI on supportive relationships with family members is contingent upon one's early weight. (All models are available from first author.) The significant interaction term model is presented in Table 3 (Model 1, lefthand panel). For ease of interpretation, the interaction terms (net of all demographic, socioeconomic status, and health variables) are plotted in Figure 1.

The interaction-term analysis reveals that for persons who were of normal weight or underweight at age 21 , current BMI is related only weakly to positive interactions with family members. Those who are currently classified as normal, overweight, and obese and who were thin or of normal weight when younger report virtually identical levels of emotional support from their family members. (The one exception is persons who did not report their adult weight; their failure to do so may be a behavioral response to nonsupportive family relations.) Among persons who were overweight or obese when they were young, however, the level of emotional support experienced in adulthood declines steadily as BMI increases. The gap in relationship quality between persons who were of normal weight and those who were overweight at age 21 widens as the current weight increases beyond the "normal" category. For instance, among persons now classified as obese II/III, levels of positive support from family are roughly one-quarter standard deviation lower if they also were overweight (versus normal or underweight) when young. Persons who were overweight in their youth but who now meet "normal" weight guidelines report much better relationships with their family than do persons who were of "normal" weight at both time points.

Pathways linking BMI to relationship quality. Our next objective is to investigate 
Table 3. OLS Regression Predicting Family Relationship Quality, by Body Mass Index (BMI), Life Course, and Health Behavior Indicators

\begin{tabular}{|c|c|c|c|c|}
\hline & & Positive Interactions & \multicolumn{2}{|c|}{ Negative Interactions } \\
\hline & Model 1 & Model 2 & Model 1 & Model 2 \\
\hline \multicolumn{5}{|l|}{ BMI } \\
\hline Underweight & $\begin{array}{c}.07 \\
(.12)\end{array}$ & $\begin{array}{l}-.14 \\
(.11)\end{array}$ & $\begin{array}{c}.01 \\
(.12)\end{array}$ & $\begin{array}{l}-.02 \\
(.12)\end{array}$ \\
\hline Overweight & $\begin{array}{r}-.30 * \\
(.15)\end{array}$ & $\begin{array}{l}-.20 \\
(.15)\end{array}$ & $\begin{array}{c}.05 \\
(.04)\end{array}$ & $\begin{array}{c}.02 \\
(.04)\end{array}$ \\
\hline Obese I & $\begin{array}{l}-.35^{*} \\
(.16)\end{array}$ & $\begin{array}{l}-.29+ \\
(.15)\end{array}$ & $\begin{array}{l}.06 \\
(.06)\end{array}$ & $\begin{array}{l}-.01 \\
(.06)\end{array}$ \\
\hline Obese II/III & $\begin{array}{l}-.55 * * * \\
(.116)\end{array}$ & $\begin{array}{l}-.48 * * \\
(.16)\end{array}$ & $\begin{array}{l}.24 * * * \\
(.07)\end{array}$ & $\begin{array}{c}.10 \\
(.08)\end{array}$ \\
\hline Missing & $\begin{array}{l}-.69 * \\
(.31)\end{array}$ & $\begin{array}{l}-.61 * \\
(.30)\end{array}$ & $\begin{array}{l}.23 * * \\
(.09)\end{array}$ & $\begin{array}{l}.17 * \\
(.09)\end{array}$ \\
\hline \multicolumn{5}{|l|}{ Life Course Indicators } \\
\hline $\begin{array}{l}\text { Relationship with mother } \\
\text { when growing up }\end{array}$ & & $\begin{array}{l}.22 * * * \\
(.02)\end{array}$ & $\begin{array}{l}-.12 * * * \\
(.02)\end{array}$ & $\begin{array}{l}-.12 * * * \\
(.02)\end{array}$ \\
\hline $\begin{array}{l}\text { Relationship with father } \\
\text { when growing up }\end{array}$ & & $\begin{array}{l}.17 * * * \\
(.02)\end{array}$ & $\begin{array}{l}-.11 * * * \\
(.02)\end{array}$ & $\begin{array}{l}-.11 * * * \\
(.02)\end{array}$ \\
\hline $\begin{array}{l}\text { BMI at age 21: normal or } \\
\text { underweight }\end{array}$ & $\begin{array}{r}-.32 * \\
(.15)\end{array}$ & $\begin{array}{l}-.20 \\
(.14)\end{array}$ & $\begin{array}{l}-.06 \\
(.05)\end{array}$ & $\begin{array}{l}-.03 \\
(.05)\end{array}$ \\
\hline \multicolumn{5}{|c|}{ Health and Health Behavior Consequences } \\
\hline $\begin{array}{l}\text { Limitations with intermediate } \\
\text { daily living activities }\end{array}$ & & & & $\begin{array}{l}.14 * * * \\
(.03)\end{array}$ \\
\hline On a special diet & & & & $\begin{array}{l}.10^{*} \\
(.05)\end{array}$ \\
\hline $\begin{array}{l}\text { Number of 10-pound weight } \\
\text { changes, ever }\end{array}$ & Delivered by Ingenta to & & & $\begin{array}{l}.01 * \\
(.005)\end{array}$ \\
\hline Interaction Terms & University of Wisconsin-M: & dison & & \\
\hline $\begin{array}{l}\text { Normal BMI at } 21 \times \\
\text { currently overweight }\end{array}$ & $\begin{array}{c}\text { Tue, } 22 \text { Dec } 2009.30+: 51 \\
(.16)\end{array}$ & $\begin{array}{l}.19 \\
(.16)\end{array}$ & & \\
\hline $\begin{array}{l}\text { Normal BMI at } 21 \times \\
\text { currently obese I }\end{array}$ & $\begin{array}{l}.39^{*} \\
(.17)\end{array}$ & $\begin{array}{l}.30^{*} \\
(.15)\end{array}$ & & \\
\hline $\begin{array}{l}\text { Normal BMI at } 21 \times \\
\quad \text { currently obese II/III }\end{array}$ & $\begin{array}{l}.59 * * \\
(.19)\end{array}$ & $\begin{array}{l}.48 * * \\
(.19)\end{array}$ & & \\
\hline $\begin{array}{l}\text { Normal BMI at } 21 \times \\
\text { weight missing currently }\end{array}$ & $\begin{array}{l}.65^{*} \\
(.32)\end{array}$ & $\begin{array}{l}.58+ \\
(.32)\end{array}$ & & \\
\hline Constant & $\begin{array}{l}.39 \\
(.16)\end{array}$ & $\begin{array}{r}-1.21 \\
(.17)\end{array}$ & $\begin{array}{c}.88 \\
(.12)\end{array}$ & $\begin{array}{c}.77 \\
(.12)\end{array}$ \\
\hline Adj. $R^{2}$ & .03 & .15 & .11 & .12 \\
\hline
\end{tabular}

Notes: $N=3,656$. Standardized coefficients are presented. "Normal weight" is the omitted category. Demographic characteristics, socioeconomic status, psychological health, and physical health are controlled in all models.

$+p \leq .10 ; * p \leq .05 ; * * p \leq .01 ; * * * p \leq .001$

possible explanations for the significant association between BMI and both supportive and problematic relationships with family. Because BMI is not linked significantly or systematically to interactions with spouse, coworkers, or friends, we did not evaluate potential mediators for those relationships. Thus we examine further the effects of BMI on positive relationships with family, based on BMI in early life. To explore whether these effects are attributable in part to family dynamics that date back to the formative years, we control for the quality of the respondent's relationship with mother and with father when he or she was growing up. Results are presented in Table 3 (Model 2, left-hand panel). For ease of interpretation, the interaction terms (net of demographic, socioeconomic status, health, and early parental relationship variables) are presented in Figure 2.

After early relationships are controlled, we still find that the link between current obesity and positive family interactions is 


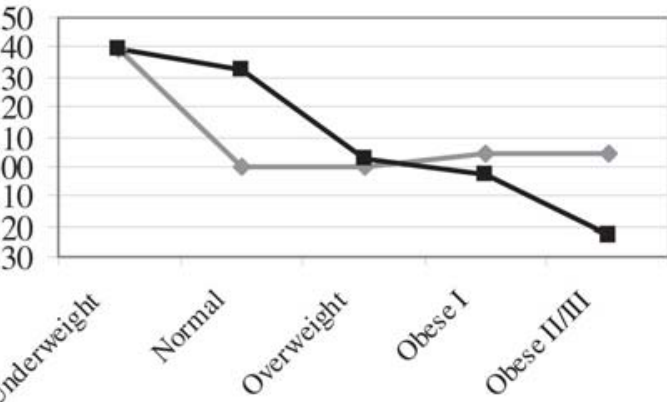

$\leadsto$ Normal/thin, age 21

$\rightarrow-$ Overweight or above, age 21

\section{Current Body Mass Index}

Figure 1. Positive Interactions With Family, by Current Weight and Weight at Age 21, Net of Demographic and Socioeconomic Characteristics

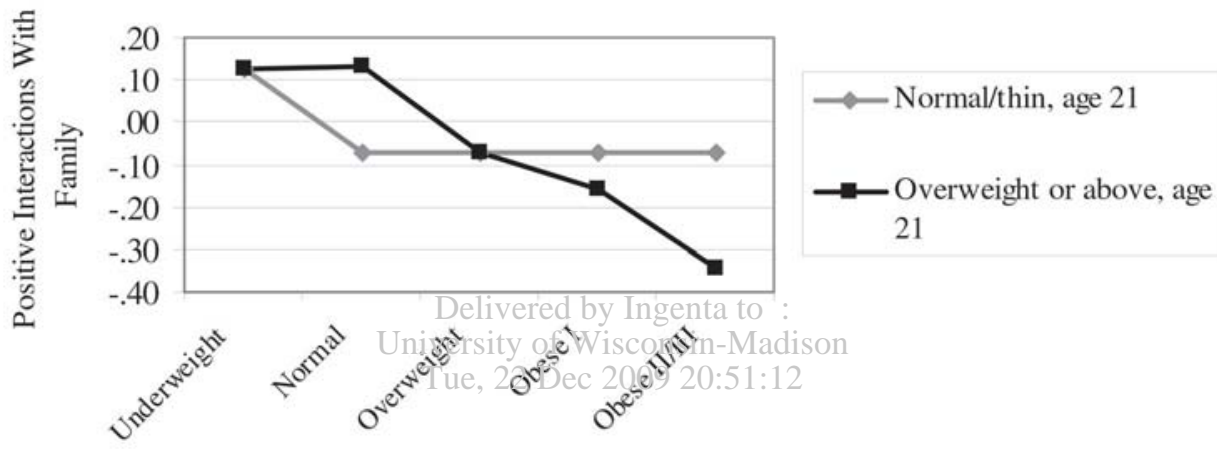

Current Body Mass Index

Figure 2. Positive Interactions With Family, by Current Weight and Weight at Age 2 1, Net of Demographic, Socioeconomic, and Early Parental Relationship Measures

contingent upon BMI in adolescence. Among persons who were overweight at a young age, each successive category of adult BMI is associated with significantly less supportive family relationships, whereas persons who were of "normal" weight earlier in life report nearly identical levels of emotional support in their familial relationships, regardless of their current weight. Obesity appears to impede the development of high-quality familial relationships only for those persons whose obesity dates back to their adolescence; individuals who are obese as adults but who enjoyed a "normal" weight in adolescence are no different from their slimmer peers in their positive interactions with family in adulthood.
Negative interactions with family, in contrast, are not affected by one's weight trajectory. Criticism from family members is affected neither by weight at age 21 , nor by combinations of current and past body weight. That is, the two-way interaction terms between current BMI and BMI at age 21 were not statistically significant in models predicting negative family relations. Thus our next objective is to evaluate other possible explanations for the link between obesity and negative family interactions. First, we evaluate whether this link can be explained by early familial relationships; second, we evaluate whether the link can be explained by health behaviors and consequences of obesity. These models are presented in the right-hand panel of Table 3 . 
Model 1 reveals that persons classified as obese II/III report more negative, critical interactions with their family members than do normal-weight persons (beta $=-.24, p \leq$ $.001)$, even when the quality of the early parent-child relationship is controlled. Although early relationships have a direct and significant effect on current levels of criticism received from family members, they do not account for the link between body weight and negative family interactions in adulthood. Rather, the negative encounters reported by very obese individuals may reflect the ways in which weight intrudes upon their current lifestyles and, in turn, on their relationship with family members. When functional limitations, dieting, and weight cycling are controlled, the relation between obese II/III status and negative family interactions is no longer statistically significant. ${ }^{7}$ Moreover, each health consequence or behavior associated with obesity affects negative family interactions directly. Persons with more functional limitations report more negative interactions (beta $=.14, p \leq .001$ ), as do persons who follow a strict diet (beta $=$ $.10, p \leq .05)$. More frequent weight cycling also is associated with more frequent criticism from, and tense interactions with, family members. In sum, family members' criticism and rejection of obese persons may reflect the intrusiveness of obesity on daily practices and routines.

\section{DISCUSSION}

Prejudicial attitudes towards obese individuals have been documented across multiple studies (Puhl and Brownell 2001). We find, however, that obese and overweight Americans do not uniformly report interpersonal relationships marked by more conflict and less warmth than do their slimmer peers. Rather, our results show that overweight and obese individuals do not differ significantly from normal-weight persons in their relationships with spouses, coworkers, or friends. We corroborated this finding when we used a

${ }^{7}$ In preliminary analyses, we found similar results in models using a continuous measure of BMI: the effect of BMI on negative interactions with family was no longer statistically significant after intrusive health behaviors were controlled. continuous measure of BMI; the continuous indicator also did not significantly predict the quality of relationships with spouses, coworkers, and friends.

In our view, these findings reflect the fact that each of these three relationships is formed and maintained voluntarily. Obese and overweight individuals, like normalweight persons, arrange their social lives so as to meet their emotional and social needs. They may either terminate unrewarding social relationships, or choose to interact only with persons who provide sufficient emotional warmth and support. Both strategies are adaptive insofar as they protect obese persons, and stigmatized persons in general, from the rejection that might ensue if they sought out friends or romantic partners from the wider social environment (Link et al. 1989).

Alternatively, the friends, spouses, and coworkers who befriend, marry, and work with obese individuals may be "wise persons" who have not fully internalized negative stereotypes about the desirability and character of obese individuals (Goffman 1963). Dur speculation is consistent with past studies showing that obese persons are less likely to marry (Gortmaker et al. 1993; Sobal, Rauschenbach and Frongillo 1995), but are more likely to marry fellow obese persons (Sackett et al.1975) and are no more likely to divorce than normal-weight persons ( $\mathrm{Fu}$ and Goldman 1996). These findings suggest that while some people would choose not to marry an obese person, those who do so are committed to their spouse and may share important characteristics with him or her.

We also found, however, that both highly obese persons and persons who did not report their weight suffer more problematic family relationships than their slimmer peers. Social norms dictate that ties with parents, siblings, and children should not be dissolved (Litwak 1981). Obese individuals who are subject to criticism or emotional coldness from family members may not feel free to sever these problematic ties. We also found that obesity is linked to both positive and negative family interactions in distinctive ways: positive relationships are a function of long-established interpersonal dynamics, whereas criticism from family members 
reflects current challenges and difficulties including intrusive health behaviors and limitations.

The most striking finding of our study is that obesity has harmful consequences for positive family relations only among those persons who also were overweight during young adulthood. Specifically, we found that for persons who were thin or of normal weight in adolescence, current BMI is related only weakly to the emotional support received from family members during adulthood. For persons who were overweight as adolescents, however, the level of emotional support received from family members in adulthood declines as adult BMI increases. Very obese persons who also were overweight or obese during childhood reported the lowest levels of emotional support from family; this finding persists even when early parent-child relationships are controlled. As revealed by a large body of literature spanning more than 40 years, even young children internalize the message that obese persons are considered less attractive, competent, desirable, and valuable than their slimmer peers (e.g., Bell and Morgan 2000; Richardson 1970). Individuals who were obese as young people thus may find that their body weight figures largely in their selfevaluations and interpersonal relationships even through adulthood, because they were socialized early on to recognize and behave in accordance with their "disadvantageous situation" (Goffman 1963:32).

Our findings are consistent with core themes of modified labeling theory (Link et al. 1989). This theory proposes that through the process of socialization, individuals develop and internalize negative beliefs about what it means to belong to a stigmatized group; thus they form beliefs about how others will view them and ultimately will treat members of that stigmatized group. Although MLT theory initially was developed to characterize the experiences of mentally ill persons, the core propositions of the theory hold for obese persons as well (Link et al. 1989). Obese persons, however, may adopt different strategies for coping with the knowledge that they are devalued by others: mentally ill persons may conceal their stigmatized identity, but obese adolescents do not have this option. The difficult interactions they experience with family members early in life may set the course for subsequent interactions in adulthood.

Our findings do not support the claim that weight loss creates family problems or disequilibrium (e.g., Blank et al. 1981; Rickarby 1981). Rather, we found that persons who were overweight early in life but of normal weight in adulthood report better familial relationships than persons who have maintained a "normal" weight over the life course. Perhaps family members provide extra emotional support to those who "improve" over the life course, and who eventually conform to societal ideals of physical attractiveness.

Negative interactions with family members, in contrast, appear to be a function of current challenges and behaviors. We found that highly obese persons reported very high levels of conflict with family members; yet this relationship was no longer statistically significant after health behaviors and limitations were controlled. Our finding is consistent with clinical studies showing that unheaithy eating behaviors, rather than obesity per se, are associated with negative family interactions (e.g., Friedman et al. 1997). These results suggest that current family strain may reflect the daily challenges associated with managing and adjusting to the "obtrusive" aspects of obese persons' lives (Goffman 1963).

Our results also suggest that evaluations of interpersonal relationships do not necessarily reflect an enduring disposition of the evaluator, such as negative affect, personality, or social desirability (e.g., Pagel, Erdly, and Becker 1987; Rook 1998). Rather, our findings suggest that individuals evaluate their relationships on the basis of distinctive and idiosyncratic aspects of their interaction with specific significant others. ${ }^{8}$ Theoretical writings on stigma suggest that "discredited" persons, including obese individuals, may bring a defensive interaction style to all of their interpersonal relationships (e.g., Goldman

${ }^{8}$ The zero-order correlations among the seven relationship quality indicators are modest, ranging from .20 to .46. (The correlation matrix is displayed in Appendix Table A1). 
and Lewis 1977; Snyder et al. 1977). Our findings suggest, alternatively, that the association between family relationships and obesity reflects distinctive aspects of family ties rather than a generalized interpersonal style of obese persons.

\section{Limitations and Future Directions}

Our study has a number of important limitations. First, we have no way of knowing who respondents use as their reference when answering questions about "your family." We presume that most think about parents, siblings, and children, given evidence that European Americans tend to define "family" in terms of these three relationships (Bedford and Blieszner 1997). Moreover, we do not know how individuals make overall assessments of the quality of their relationships when the reference group (such as "friends") comprises multiple persons. Some may focus on the most negative member of their social circle; others may focus on the most encouraging. Additional research is needed to identify the ways in which overweight and obese individuals interact with specific significant others, and how these specific interactions affect interpersonal dynamics and relationships in general.

Second, our evaluations of positive and negative interactions reflect only perceptions: we cannot corroborate the respondents' evaluations with the evaluations offered by their significant others. Perceptions are important in their own right, however, and may have important consequences for the perceiver (Thomas and Znaniecki 1918). If obese people perceive that their family members view them negatively, this perception may discourage them from seeking emotional or instrumental support. In addition, the MIDUS does not obtain data on the personal characteristics of the respondents' significant others, including their body weight. The extent to which one's body weight affects personal relationships may be contingent upon the body weight of one's significant others. Future studies should include rigorous empirical evaluations of Goffman's (1963) concept of "sympathetic others," and should ascertain whether obese individuals enjoy more rewarding relation- ships with significant others who also are overweight or obese.

Third, we assess only a limited number of factors that may account for the association between obesity and relationship quality. Moreover, because the MIDUS was not designed expressly to investigate the interpersonal consequences of obesity, several of the health behavior measures are not ideal. In particular, our indicator of dieting is quite broad, and includes special diets intended for health maintenance rather than for weight loss only. Future research should consider a wider array of "obtrusive" health behaviors and practices of obese persons that may affect their interpersonal relationships. For instance, emerging research shows that obese binge eaters report poorer psychological health, more interpersonal problems, and more disturbed family relationships than obese persons who do not engage in binge eating (Friedman and Brownell 1995; Friedman et al. 1997). The extent to which family members try to control the health behaviors of obese individuals also may affect the nature and quality of their interpersonal relationships.

Fourth, because the MIDUS data are cross-sectional, we cannot ascertain causal order nor processes of social selection. For instance, we cannot determine definitively whether current BMI is a cause or a consequence of problematic relationships, although we found that the significant association between obesity and quality of current family relationships persisted when we controlled indicators of early parent-child relationships. Moreover, because the data are cross-sectional, we cannot identify those persons who have dissolved unsatisfying marriages, friendships, or workplace relationships. Persons in the most severely strained marriages or work situations, for instance, may exit these relationships and instead may pursue new relationships that are emotionally satisfying. Future studies should explore the associations between body weight and the trajectories of interpersonal relationships.

Fifth, our operationalization of weight trajectory is very broad, and cannot pinpoint the precise stage in the life course when an individual lost or gained significant weight. 
Rather, we compare self-reported weight at age 21 with adult weight. The long-term consequences of early-life obesity and changes in weight may be conditional on the age of onset of obesity, or on the point in the life course when an individual's weight changed considerably (George 1993). The extent to which one adopts the identity of a stigmatized person may be contingent both on the age at which he or she experienced obesity and on the duration of this experience. Moreover, experiences of adolescent obesity are more recent for younger sample members, and may have more powerful implications for the nature and quality of their adult relationships. Finally, the coarse indicator signified only whether the respondent was normal or underweight versus overweight earlier in life; it does not capture the long-term con- sequences of different levels of obesity in early life.

Despite these limitations, our study has shown that obesity does not necessarily impair interpersonal relationships. The weakness or inconsistency of the link between BMI and interpersonal relationships is consistent with research on the psychological health of obese individuals: despite strong theoretical rationale for the notion that obesity should be a source of psychological distress and poor self-esteem, most empirical analyses do not support this claim (for a review, see Friedman and Brownell 1995). Future research not only should explore the sources of psychosocial resilience among obese persons, but also should also identify the distinctive characteristics of subgroups of obese persons whose interpersonal relationships are compromised.

Appendix Table A1. Zero-Order Correlations Among Relationship Quality Indicators

(1)

(2)

(3)

(4)

(5)

(6)

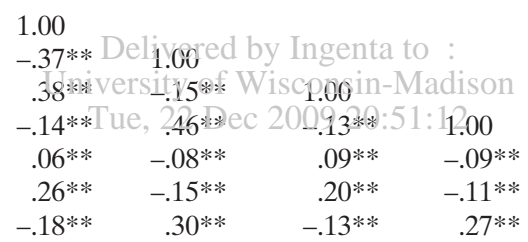
1.00
.04

$-.05^{*}$
1.00

$-.62 * *$ 1.00

\section{REFERENCES}

Allon, Natalie. 1981. "The Stigma of Overweight in Everyday Life." Pp. 130-74 in Psychological Aspects of Obesity: A Handbook, edited by Benjamin B. Wolman. New York: Van Nostrand Rheinhold.

Antonucci, Toni C. 2001. "Social Relations: An Examination of Social Networks, Social Support, and Sense of Control." Pp. 427-53 in Handbook of the Psychology of Aging, 5th ed., edited by James E. Birren and K. Warner Schaie. San Diego: Academic Press.

Averett, Susan L. and Sanders Korenman. 1999.

"Black-White Differences in Social and Economic Consequences of Obesity." International Journal of Obesity 23:166-73.

Banis, Heather, James Verne, Jan Wallender, and Barbara Korsch. 1988. "Psychological and Social Adjustment of Obese Children and Their Families." Child Care Health and Development 14:157-73.

Barbarin, Oscar and Mildred Tirado. 1994. "Family
Involvement and Successful Treatment of Obesity: A Review." Family Systems Medicine 2:37-45.

Bartlett, Susan J., Thomas A. Wadden, and Renee A. Vogt. 1996. "Psychosocial Consequences of Weight Cycling." Journal of Consulting and Clinical Psychology 64:587-92.

Bedford, Victoria and Rosemary Blieszner. 1997. "Personal Relationships in Later Life Families." Pp. 523-39 in Handbook of Personal Relationships, 2nd ed., edited by Steve Duck. New York: Wiley.

Bell, Stephen K. and Sam B. Morgan. 2000. “Children's Attitudes and Behavioral Intentions Toward a Peer Presented As Obese: Does a Medical Explanation for the Obesity Make a Difference?" Journal of Pediatric Psychology 25:137-45.

Blank, V.E., M. J. Herman, A. Kumis, and W. J. Vitale. 1981. "Jealous Husband Threatens Diet." Obesity and Bariatric Medicine 10:104-108.

Bowman, R. L., and J. L. DeLuca. 1992. “Accuracy 
of Self-reported Weight: A Meta-Analysis." Behavior Therapy 23:637-56.

Brim, Orville Gilbert, Carol D. Ryff, and Ronald C. Kessler. 2004. "The MIDUS Survey: An Overview." Pp. 1-34 in How Healthy Are We? A National Study of Well-Being at Midlife, edited by Orville G. Brim, Carol D. Ryff, and Ronald C. Kessler. Chicago: University of Chicago Press.

Buhrmester, Duane, Wyndol Furman, Mitchell Wittenberg, and Harry T. Reis. 1988. "Five Domains of Interpersonal Competence in Peer Relationships." Journal of Personality and Social Psychology 55:991-1008.

Cahnman, Werner J. 1968. "The Stigma of Obesity." Sociological Quarterly 9:283-99.

Carr, Deborah and Michael Friedman. 2005. "Is Obesity Stigmatizing? Body Weight, Perceived Discrimination, and Psychological Well-Being in the United States.” Journal of Health and Social Behavior 46:244-59.

Cash, Thomas F., Brenda Counts, and Christopher E. Huffine. 1990. "Current and Vestigial Effects of Overweight Among Women: Fear of Fat, Attitudinal Body Image, and Eating Behaviors." Journal of Psychopathology and Behavioral Assessment 12:157-67.

Centers for Disease Control (CDC). 2000. CDC Growth Charts for the United States: Methods and Development. Washington, DC: Centers for Disease Control.

Christoffel, Katherine and Brian W. Forsyth. 1989. "Mirror Image of Environmental Deprivation: Severe Childhood Obesity of Psychosocial Origin." Child Abuse and Neglect 13:249-56.

Cohen, Sheldon and S. Leonard Syme. 1985. "Issues in the Application and Study of Social Support." Pp. 3-22 in Social Support and Health, edited by Sheldon Cohen and S. Leonard Syme. Orlando: Academic Press.

Constanzo, Philip R. and Erik Z. Woody. 1985. "Domain-Specific Parental Styles and Their Impact on the Child's Development of Particular Deviance: The Example of Obesity Proneness." Journal of Social and Clinical Psychology 3:425-30.

Coyne, James C. 1976. "Depression and the Response of Others." Journal of Abnormal Psychology 85:186-93.

Coyne, James C., Ronald C. Kessler, Margalit Tal, Joanne Turnbull, Camille Wortman, and John F. Greden. 1987. "Living With a Depressed Person." Journal of Consulting and Clinical Psychology 55:347-52.

Craig, P.L. and A. Stewart Truswell. 1990. "Dynamics of Food Habits of Newly Married Couples: Weight and Exercise Patterns." Australian Journal of Nutrition and Dietetics 47:42-46.
Crandall, Christian S. and Rebecca Martinez. 1996. "Culture, Ideology, and Anti-Fat Attitudes." Personality and Social Psychology Bulletin 22:1165-76.

Crandall, Christian S. and Kristin L. Schiffhauer. 1998. "Anti-Fat Prejudice: Beliefs, Values, and American Culture." Obesity Research 6:458-60.

Crocker, Jennifer and Brenda Major. 1989. "Social Stigma and Self-Esteem: The Self-Protective Properties of Stigma." Psychological Review 96:608-30.

Crocker, Jennifer, Brenda Major, and Claude Steele. 1998. "Social Stigma." Pp. 504-33 in The Handbook of Social Psychology, edited by Daniel T. Gilbert and Susan T. Fiske. Boston: McGraw-Hill.

Cutting, Tanja M., Jennifer O. Fisher, Karen Grimm-Thomas, and Leann L. Birch. 1999. "Like Mother, Like Daughter: Familial Patterns of Overweight Are Mediated by Mother's Dietary Disinhibition." American Journal of Clinical Nutrition 69:608-13.

DeJong, William. 1980. "The Stigma of Obesity: The Consequences of Naïve Assumptions Concerning the Causes of Physical Deviance." Journal of Health and Social Behavior 21:75-87.

Doherty, William J. and Jill E. Harkaway. 1990.

sconsiar Obesity and Family Systems: A Family FIRO Approach to Assessment and Treatment Planning." Journal of Marital and Family Therapy 16:287-98.

Ferraro, Kenneth F. and Jessica A. Kelley-Moore. 2003. "Cumulative Disadvantage and Health: Long-Term Consequences of Obesity." American Sociological Review 68:707-29.

Finch, John F., Morris A. Okun, Gregory Pool, and Linda S. Ruhlman. 1999. "A Comparison of the Influence of Conflictual and Supportive Social Interactions on Psychological Distress." Journal of Personality 67:581-621.

Fischer, Claude S. 1982. To Dwell Among Friends. Chicago: University of Chicago Press.

Flegal, Katherine M., Margaret D. Carroll, Cynthia Ogden, and Clifford L. Johnson. 2002. "Prevalence and Trends in Obesity Among U.S. Adults, 1999-2000." Journal of the American Medical Association 288:1723-27.

Friedman, Kelli E., Simona K. Reichmann, Philip R. Constanzo, and Gerard J. Musante. 2002. "Body Image Partially Mediates the Relationship Between Obesity and Psychological Distress." Obesity Research 10:33-41.

Friedman, Michael A. and Kelly D. Brownell. 1995. "Psychological Correlates of Obesity: Moving to the Next Research Generation." Psychological Bulletin 117:3-20. 
Friedman, Michael A., Denise E. Wilfley, R. Robinson Welch, and Joseph T. Kunce. 1997. "Self-Directed Hostility and Family Functioning in Normal-Weight Bulimics and Overweight Binge Eaters." Addictive Behaviors 22:367-75.

$\mathrm{Fu}$, Haishan and Noreen Goldman. 1996. "Incorporating Health Into Models of Marriage Choice: Demographic and Sociological Perspectives." Journal of Marriage and the Family 58:740-58.

Ganley, Richard M. 1986. "Epistemology, Family Patterns, and Psychosomatics: The Case of Obesity." Family Process 25:437-51.

George, Linda. 1993. "Sociological Perspectives on Life Transitions." Annual Review of Sociology 19:353-73.

Giesler, R. Brian, Robert A. Josephs, and William B. Swann Jr. 1996. "Self-Verification in Clinical Depression:The Desire for Negative Evaluation." Journal of Abnormal Psychology 105:358-68.

Goffman, Erving. 1963. Stigma: Notes on the Management of Spoiled Identity. Englewood Cliffs, NJ: Prentice-Hall.

Goldman, William and Philip Lewis. 1977. "'Beautiful Is Good': Evidence That the Physically Attractive Are More Socially Skillful." Journal of Experimental Sofial Psychology 13:125-30.

Gortmaker, Steven L., Aviva Must, James M. Perrin, Arthur M. Sobol, and William H. Dietz. 1993. "Social and Economic Consequences of Overweight in Adolescence and Young Adulthood." New England Journal of Medicine 329:1008-12.

Gotlib, Ian H. and Sari J. Meltzer. 1987. "Depression and the Perception of Social Skill in Interaction." Cognitive Therapy and Research 11:41-54.

Greenberg, Bradley S., Matthew Eastin, Linda Hotschire, Ken Lachlan, and Kelly D. Brownell. 2003. "Portrayals of Overweight and Obese Individuals on Commercial Television." American Journal of Public Health 93:1342-48.

Harris, Mary B., Richard J. Harris, and Stephen Bochner. 1982. "Fat Four-Eyed and Female: Stereotypes of Obesity, Glasses and Gender." Journal of Applied Social Psychology 12:503-16.

House, James S., Karl R. Landis, and Debra Umberson. 1988. "Social Relationships and Health.” Science 241:540-45.

Levitt, Mary J., Marcia E. Silver, and Nathalie Franco. 1996. "Troublesome Relationships: A Part of Human Experience." Journal of Social and Personal Relationships 13:523-36.

Link, Bruce G. and Jo C. Phelan. 2001.
"Conceptualizing Stigma." Annual Review of Sociology 27:363-85.

Link, Bruce G., Elmer Streuning, Francis T. Cullen, Patrick E. Shrout, and Bruce P. Dohrenwend. 1989. “A Modified Labelling Theory Approach to Mental Disorders: An Empirical Assessment." American Sociological Review 54:400-23.

Litwak, Eugene. 1981. The Modified Extended Family, Social Networks, and Research Continues in Aging. New York: Columbia University Center for Social Sciences.

Lissau, Inge and Thorkild I.A. Sorensen. 1994. "Parental Neglect During Childhood and Increased Risk of Obesity in Young Adulthood." Lancet 343:324-27.

Lumeng, Julie C., Kate Gannon, Howard Cabral, Deborah A. Frank, and Barry Zuckerman. 2003. "Association Between Clinically Meaningful Behavior Problems and Overweight in Children." Pediatrics 112:1138-45.

Margolin, Leslie and Lynn White. 1987. "The Continuing Role of Physical Attractiveness in Marriage." Journal of Marriage and the Family 49:21-27.

McLaughlin, Julie, Allan V. Horwitz, and Helene Raskin White. 2002. "The Differential Importance of Friend, Relative, and Partner Relationship for the Mental Health of Young Adults." Social Networks and Health 8:223-46.

McPherson, Miller, Lynn Smith-Lovin, and James M. Cook. 2001. "Birds of a Feather: Homophily in Social Networks." Annual Review of Sociology 27:415-44.

Miller, Carol T., Esther D. Rothblum, Linda Barbour, Pamela A. Brand, and Diane M. Felicio. 1990. "Social Interactions of Obese and Non-Obese Women." Journal of Personality 58:365-80.

Miller, Carol T., Esther D. Rothblum, Pamela A. Brand, and Diane M. Felicio. 1995. "Do Obese Women Have Poorer Social Relationships Than Non-Obese Women? Reports by Self, Friends and Coworkers." Journal of Personality 63:65-85.

Mok dad, Ali, Mary Serdula, William Dietz, Barbara Bowman, James Marks, and Jeffrey Koplan. 1999. "The Spread of the Obesity Epidemic in the United States, 1991-1998." Journal of the American Medical Association 282:1519-22.

National Heart, Lung, and Blood Institute [NHLBI]. 1998. Clinical Guidelines on the Identification, Evaluation, and Treatment of Overweight and Obesity in Adults. Bethesda, MD: National Institutes of Health.

Nevid, Jeffrey S. 1984. "Sex Differences in Factors 
in Romantic Attraction." Sex Roles 11:401-11.

Ogden, Cynthia L., Katherine M. Flegal, Margaret D. Carroll, and Clifford L. Johnson. 2002. "Prevalence and Trends in Overweight Among U.S. Children and Adolescents, 1999-2000." Journal of the American Medical Association 288:1728-32.

Okun, Morris A. and Verna M. Keith. 1998. "Effects of Positive and Negative Social Exchanges With Various Sources on Depressive Symptoms in Younger and Older Adults." Journal of Gerontology: Psychological Sciences 53B:4-20.

Pagel, Mark D., William W. Erdly, and Joseph Becker. 1987. "Social Networks: We Get By With (and in Spite of) a Little Help From Our Friends." Journal of Personality and Social Psychology 53:793-804.

Palta, Mari, Ronald J. Prineas, Reuben Berman, and Peter Hannan. 1982. "Comparison of Self-Reported and Measured Height and Weight." American Journal of Epidemiology 115:223-30.

Puhl, Rebecca and Kelly D. Brownell. 2001. "Bias, Discrimination and Obesity." Obesity Research 9:788-805.

. 2003. "Ways of Coping With Obesity Stigma: Review and Conceptual Anarysis." Eating Behaviors 4:53-78.

Richardson, Stephen A. 1970. "Age and Sex Differences in Values Toward Physical Handicaps." Journal of Health and Social Behavior 11:207-14.

Rickarby, Geoff A. 1981. "Psychological Dynamics in Obesity." Medical Journal of Australia 3:602-605.

Rook, Karen S. 1984. "The Negative Side of Social Interaction: Impact on Psychological WellBeing." Journal of Personality and Social Psychology 46:1097-1108.

-. 1998. "Investigating the Positive and Negative Sides of Personal Relationships: Through a Lens Darkly?" Pp. 369-93 in The Dark Side of Close Relationships, edited by Brian H. Spitzberg and William R. Cupach. Mahwah, NJ: Erlbaum.

Ross, Catherine E. 1994. "Overweight and Depression." Journal of Health and Social Behavior 35:63-79.

Sackett, David L., G. D. Anderson, Russell Millner, Manning Feinleib, and William B. Kannel. 1975. "Concordance for Coronary Risk Factors for Spouses.” Circulation 52:589-95.

Schneider, Joseph and Peter Conrad. 1980. "In the Closet With Illness: Epilepsy, Stigma Potential, and Information Control." Social Problems 28:32-44.

Snyder, Eric E., Brandon Walts, Louis Perusse, Yvon C. Chagnon, S. John Weisnagel, Tuomo
Rankinen, and Claude Bouchard. 2004. "The Human Obesity Gene Map: The 2003 Update." Obesity Research 12: 369-439.

Snyder, Mark, Elizabeth D. Tanke, and Ellen Berscheid. 1977. "Social Perception and Interpersonal Behavior: On the SelfFulfilling Nature of Social Stereotypes." Journal of Personality and Social Psychology 35:656-66.

Sobal, Jeffrey, Vasiliki Nicolopoulos, and Jennifer Lee. 1995. "Attitudes About Weight and Dating Among Secondary School Students." International Journal of Obesity Research 19:376-81.

Sobal, Jeffrey, Barbara A. Rauschenbach, and Edward A. Frongillo Jr. 1992. "Marital Status, Fatness and Obesity." Social Science and Medicine 35:915-23.

- 1995. "Obesity and Marital Quality: Analysis of Weight, Marital Unhappiness, and Marital Problems in a U.S. National Sample." Journal of Family Issues 16:768-86. . 2003. "Marital Status Changes and Body Weight Changes: A U.S. Longitudinal Analysis." Social Science and Medicine 56:1543-55.

Sobal, Jeffrey and Albert J. Stunkard. 1989. "Socioeconomic Status and Obesity: A Review of the Literature." Psychological Ballein 105:260-75.

Strauss, Richard S. and Harold A. Pollack. 2003. "Social Marginalization of Overweight Children." Archives of Pediatrics and Adolescent Medicine 157:746-53.

Stuart, Richard B. and Barbara Jacobson. 1987. Weight, Sex, and Marriage: A Delicate Balance. New York: Norton.

Stunkard, Albert J. and Janet M. Albaum. 1981. "The Accuracy of Self-Reported Weights." American Journal of Clinical Nutrition 34:1593-99.

Taylor, Humphrey. 1998. Differences in American and Japanese Attitudes to Extramarital Sex and Divorce. Rochester, NY: Louis Harris and Associates.

Thomas, William I. and Florian Znaniecki. 1918. The Polish Peasant in Europe and America. New York: Dover.

Van Itallie, Theodore B. 1985. "Health Implications of Overweight and Obesity in the United States." Annals of Internal Medicine 103:983-88.

Vinokur, Amiram D. and Michelle van Ryn. 1993. "Social Support and Undermining in Close Relationships: Their Independent Effects on the Mental Health of Unemployed Persons." Journal of Personality and Social Psychology 65:350-59.

Wardle, Jane, Jo Waller, and Emily Fox. 2002. "Age 
of Onset and Body Dissatisfaction in Obesity." Addictive Behaviors 27:561-73.

Weihs, Karen, Larry Fisher, and Macaran Baird. 2002. "Families, Health, and Behavior." Family Systems and Health 20:7-46.

Weiss, Robert S. 1991. "The Attachment Bond in Childhood and Adulthood." Pp. 66-76 in Attachment Across the Lifecycle, edited by Colin Murray Parkes, Joan StevensonHinde, and Peter Marris. London: Tavistock.
Wellman, Barry, Renita Y. Wong, David Tindall, and Nancy Nazer. 1996. "A Decade of Network Change: Turnover, Persistence, and Stability in Personal Communities." Social Networks 19:27-50.

World Health Organization (WHO). 1998. Obesity: Preventing and Managing the Global Epidemic: Report of WHO Consultation on Obesity. Geneva: World Health Organization.

Deborah Carr is an associate professor in the Department of Sociology and the Institute for Health, Health Care Policy, and Aging Research at Rutgers University. Her research focuses on the psychological consequences of work and family roles over the life course. In her current projects she investigates the psychological consequences of social roles and stigmatized identities, and the ways in which older adults and their families prepare for the end of life. In September 2006, she will join the Department of Sociology at University of Wisconsin-Madison.

Michael Friedman is an assistant professor in the Department of Psychology and the Institute for Health, Health Care Policy, and Aging Research at Rutgers University. His research focuses on understanding and treating depression among individuals with chronic physical conditions such as obesity and cardiovascular disease. 